\begin{tabular}{|c|c|c|c|c|c|}
\hline ISRA (India) & $=3.117$ & SIS (USA) & $=0.912$ & ICV (Poland) & $=6.630$ \\
\hline ISI (Dubai, U. & $=0.829$ & РИНЦ (Russia) & $=0.156$ & PIF (India) & $=1.940$ \\
\hline GIF (Australia) & $=0.564$ & ESJI (KZ) & $=8.716$ & IBI (India) & $=4.260$ \\
\hline JIF & $=1.500$ & SJIF (Morocco) & $=5.667$ & OAJI (USA) & $=0.350$ \\
\hline
\end{tabular}

\section{SOI: $1.1 /$ TAS $\quad$ DOI: $10.15863 / \mathrm{TAS}$ International Scientific Journal Theoretical \& Applied Science}

\author{
p-ISSN: 2308-4944 (print) e-ISSN: 2409-0085 (online) \\ Year: 2019 Issue: $04 \quad$ Volume: 72
}

Published: 19.04.2019 http://T-Science.org
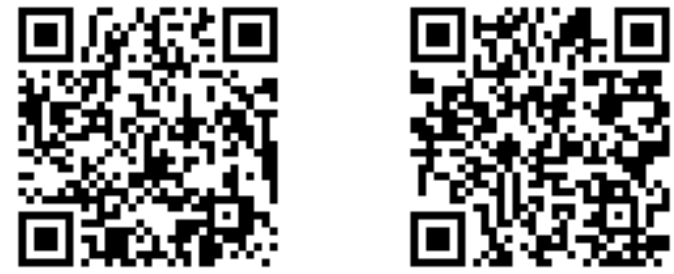

Majit Janizaqovich Bauetdinov senior teacher,

Tashkent state economic university The chair "Industrial economy"

\title{
FINANCING OF INVESTMENT EXPENSES OF MANAGING SUBJECTS
}

Abstract: In article investment activity of managing subjects is considered carried out by means of investment resources formed by them. In market economy sources of formation of investment resources are rather diverse. As a rule, all sources of financing of investments subdivide on centralized and off-budget and the basic methods of financing of investment projects are: self-financing, participation financing; credit financing; design financing.

Optimum structure of sources of financing of investments is that structure which provides the greatest profitability of own means. Therefore at a choice of this or that source of financing of investments, whether it be external or internal sources, it is necessary to start with necessity of achievement of the greatest economic benefit. The basic criteria of a choice of sources of financing of investments are cost of attraction of a concrete source, availability, life cycle of the enterprise and the concrete investment project, risks, efficiency etc.

Key words: financing sources, investment resources, bank costs, investment intermediaries, business strategy, and capital forming investments.

Language: English

Citation: Bauetdinov, M. J. (2019). Financing of investment expenses of managing subjects. ISJ Theoretical \& Applied Science, 04 (72), 188-192.

Soi: http://s-o-i.org/1.1/TAS-04-72-25 Doi: crossef https://dx.doi.org/10.15863/TAS.2019.04.72.25

\section{Introduction.}

One of the major priorities of a financial policy of Republic of Uzbekistan is wide realization of target investment programs, regulation and stimulation of investment activity of banks that demands perfection of management by process of financing of objects of real investment in shape of capital forming investments.

Commercial banks, carrying out a role of investment intermediaries, act, in turn, as a source of alternative investment resources for real investment, except the state. At the heart of the, objects of financing and crediting by commercial banks of investment projects is activity of subjects of a private sector. At the same time the state, in the name of development an institute does not undertake to finance investment projects of private businessmen in the conditions of market relations. As a rule, in this case, the state, for the purpose of stimulation of investment activity of businessmen can select only for financing only the most interesting projects. And financial support appears only on individual share principles through in the development institutes. Thus, a private sector, including banks of the second level, the basic risks of financing of investment projects are compelled to incur. In this connection, bank costs at financing of investment projects grow, and the risk regularly accompanies process of investment because of negative influence on investment process of various business factors. Many investment projects offered by subjects of managing to banks still have no reliable maintenance, the deep marketing study, in details counted feasibility report and strategy of business, own share of capital investments. These indicated factors, in turn, complicate process of financing by banks of investment projects. One of ways of the decision of the given problems, in our opinion, is perfection of system of financing by banks of investment projects. The urgency of the chosen theme of research also consists in it.

\section{Research methods.}

At work performance following methods of the scientific analysis was used: the system approach, the comparative analysis, comparison, statistical methods of processing of the information, dynamic methods of the analysis, expert estimations.

\section{Discussion.}

Activization of activity of banks in shape capital forming investments into objects of enterprise activity is the integral condition of successful development of 


\begin{tabular}{|c|c|c|c|c|c|c|}
\hline \multirow{4}{*}{ Impact Factor: } & ISRA (India) & $=3.117$ & SIS (USA) & $=0.912$ & ICV (Poland) & $=6.630$ \\
\hline & ISI (Dubai, UAE & $=0.829$ & РИНЦ (Russia) & $=0.156$ & PIF (India) & $=1.940$ \\
\hline & GIF (Australia) & $=0.564$ & ESJI (KZ) & $=8.716$ & IBI (India) & $=4.260$ \\
\hline & JIF & $=1.500$ & SJIF (Morocco & $=5.667$ & OAJI (USA) & $=0.350$ \\
\hline
\end{tabular}

economy as a whole. It is connected by that forms of investment investments carried out by banks in objects of real investment as investment crediting, financing of investment projects are favorable not only to separate banks, but also other subjects of managing. So, giving on credit certain investment resources banks, in turn, finance also investment programs of the borrowers, satisfying with that for a certain time their requirements for financial assets. But thus, it is necessary to recognize that both at bank level, and at level of subjects of managing it is impossible to carry out process of realization of large perspective investment programs without appropriate preparation of investment projects with which help each subject of the market receives real possibility of attraction from the outside of means in the form of investment investments.

From a position of world experience it is accepted to distinguish three principal views of design financing: crediting with the right of full recourse at which the creditor reserves the right of full indemnification concerning all obligations of the borrower; crediting with the right of partial recourse at which creditors have the limited right of transfer to the borrower of responsibility for credit repayment; crediting without the recourse right at which creditors incur the majority of risks. If the creditor manages to reserve the right of full recourse to the founderinitiator concerning all obligations under the project such credit is equated to the usual provided credit. In this case actually the principle of design financing specified above about division of risks as the founder bears responsibility on all risks of the project is not carried out. The given kind of design financing is the most simple, and it can be organized rather quickly and cheaply. In particular, this kind is applied, when the project is too small that additional expenses have been made, or it makes a part more the large-scale project.

Financing with the right of partial recourse as a kind of design financing, it is most extended as all risks under the project are distributed between participants so that each of them has been taken up by that party which could estimate and insure the risk taken up in the best way.

For example, it can be provided that responsibility of founders for credit repayment extends only for building and object commissioning; thus creditors incur all risks after the project starts to operate. At financing of the project without the right of recourse creditors actually incur responsibility for realization of the investment project. This kind of design financing is very expensive and consequently seldom meets in practice. At the same time, in process of growth of a competition among financially-credit institutes of the developed countries in the market of design financing, in process of perfection of methodology and practice of design financing and, especially, quality of developed business plans, and also management methods projects the number of the projects financed without the right of recourse, continuously increases.

The role of bank sector actively increases in financing of corporate sector of economy.

However, despite increase in a role of bank financing, it still is substantially used for financing of current requirements of subjects of managing, rather than for long-term investments into manufacture development.

The incentive aspect of application of financial toolkit consists in aspiration of bank managers to optimize management of risks not only at the expense of legal, legal, organizational tools, but also thanks to acceptance of additional financial measures on their minimization, not for operating thus, actives of the design company.

There is a number of features of application credit derivate, distinguishing them from other tools of management of bank risks:

1. Credit derivate allows carrying out a diversification of risks on actives, regions, branches, terms, the markets.

2. Credit derivate hedge risks during all period of action of a base active (in difference, for example, from the insurance of risks concluded on an urgent basis).

The design organization acting in a role of the borrower, does not participate in process of the conclusion of the contract, and the bank and the party buying risk, are not obliged to notify her on the transaction conclusion.

Credit derivate are tools of calculations, that is at approach of credit or brave event the seller of protection carries out immediate payment to the buyer of protection in the size, defined at the transaction conclusion.

Feature of application credit derivate is that the design company-borrower as at occurrence of time difficulties at the company and the delays of payments caused by it, the bank which carrying out financing and has received payment on derivate, with much bigger probability will go on negotiations about debt re-structuring, rather than is interested in it also than will involve the tool of initiation of bankruptcy of the company.

The documentation necessary for carrying out of operations with credit derivate is unified now by the International association of dealers on swaps and derivate (ISDA), created in 1997 the complete set of documents consists of the special form under transactions and the arch of definitions of the terms used at carrying out of operations.

7. Credit derivate is for bank the balance financial tools. At the same time, credit derivate allows to transfer risks on other party without transition of the property right to an active subject to risk. 


\begin{tabular}{|c|c|c|c|c|c|c|}
\hline \multirow{4}{*}{ Impact Factor: } & ISRA (India) & $=3.117$ & SIS (USA) & $=0.912$ & ICV (Poland) & $=6.630$ \\
\hline & ISI (Dubai, UAE & $=0.829$ & РИНЦ (Russia & $=0.156$ & PIF (India) & $=1.940$ \\
\hline & GIF (Australia) & $=0.564$ & ESJI (KZ) & $=8.716$ & IBI (India) & $=4.260$ \\
\hline & JIF & $=1.500$ & SJIF (Morocco & $=\mathbf{5 . 6 6 7}$ & OAJI (USA) & $=0.350$ \\
\hline
\end{tabular}

The listed features testify that in process of increase of integration and institutional the bank sector application of credit derivative tools will be widely adopted and in the Uzbekistan bank market. In the Uzbekistan banks managers still up to the end have not realized advantage of application of these tools not only at management of risks, but, at forming specifications, and at securitization of actives.

Design financing is one of ways of attraction of investments which represents attraction in the project of the means as which source of return the planned monetary stream of this project while at commercial and investment credits as a source of repayment of the credit the general activity of the borrower, as a rule, serves. An important component of attraction of means under the project is structuration of the scheme of financing so that to achieve the maximum effect for the borrower.

Definitions of design financing are assumed by decrease in risks of the initiator and, accordingly, increases risks of the financing party.

Depending on what share of risk is perceived on itself by the creditor, allocate 3 forms of design financing:

- With full recourse on the borrower;

- Without any recourse on the borrower;

- With the limited recourse on the borrower.

Financing with full recourse on the borrower are more widespread form of design financing. To the given form prefer in view of speed and simplicity of reception of the necessary means for project financing, and, not including that, the price of the given form of financing more low, than at two others. applied:

That form of financing in following variants is

1. Granting of means for financing of not profitable or noncommercial projects which customers have possibility to extinguish credits at the expense of other incomes of the borrower. That concern, the projects having a social orientation;

2. Granting of means in the form of the export credit. Many specialized agencies on granting of export credits have possibility to perceive on themselves dangers of projects without additional guarantees of the third parties, but thus agree to give means only in that form;

3. Insufficient reliability of the guarantees which have been given out under the project;

4. Granting of means for the small projects very sensitive even to small increase of expenses.

At design financing without recourse on the borrower the creditor has no guarantees from the borrower and perceives on itself almost all dangers connected with realization of the project. This form of financing has the higher the price for the borrower as the creditor hopes to obtain appropriate compensation for the higher degree of risk.

Without recourse on the borrower the projects having the higher profitableness and giving as a result of realization competitive production are financed traditionally [1].

Now extensive distribution receives design financing with the limited recourse on the borrower. In this case during project financing all dangers connected with its realization are estimated, and distributed between all participants of the project in that image that everyone could incur dangers depending on it.

Popularity of the form of financing of the project with the limited recourse on the borrower is explained by smaller action on a financial position of the borrower in comparison with other forms.

Unlike usual kinds of crediting, the design financing not only permits to estimate solvency of the borrower, to make out the investment project, dangers on it, but also permits to predict a result.

All it gives the chance to make not only the viable enterprise, but also to involve investors.

Last years the securitization becomes one of the pivotal sources of financing for the companies and banks all over the world. Nevertheless, securitization in Uzbekistan, despite a number of advantages, it is used insufficiently.

Therefore, extremely important in due time, to designate possibilities securitization of financial actives, and also to reveal the basic obstacles and problems in a way of development is give the innovative technics of financing.

Proceeding from the aforesaid, it is possible to draw a conclusion that securitization actives represents the innovative technics of financing based on write-off of financial actives from balance of the managing subject and their refinancing by means of release of securities in the international market and the market of capitals [2]. Securitization successfully competes to other ways of refinancing, including, with the factoring loan on the security of monetary requirements will provide a concession and others.

Mechanisms of securitization financial actives have a complex character. Research of problems securitization is expedient for spending in aggregate the account of economic and legal factors. World experience shows that distribution of use of mechanisms securitization occurs in the conditions of the generated market of mortgage and consumer credits.

Development of the given field of activity in Uzbekistan has caused requirement in securitization.

Development prospects securitization in Uzbekistan depend on the decision of a following complex of problems:

-Legal maintenance securitization;

- Expansions of system of warranting (use not only the state guarantees or guarantees of the western companies having popularity in the world market, but also domestic guarantors);

-Maintenance of other state support, except granting of guarantees. In particular in the form of 


\begin{tabular}{|c|c|c|c|c|c|c|}
\hline \multirow{4}{*}{ Impact Factor: } & ISRA (India) & $=3.117$ & SIS (USA) & $=0.912$ & ICV (Poland) & $=6.630$ \\
\hline & ISI (Dubai, UAE & $=0.829$ & РИНЦ (Russia) & $=0.156$ & PIF (India) & $=1.940$ \\
\hline & GIF (Australia) & $=0.564$ & ESJI (KZ) & $=8.716$ & IBI (India) & $=4.260$ \\
\hline & JIF & $=1.500$ & SJIF (Morocco & $=5.667$ & OAJI (USA) & $=0.350$ \\
\hline
\end{tabular}

creation of the special organizations, the preferential taxation of the securities provided with actives;

- Assignments and increases of a credit rating of banks and securities;

-Creations of the secondary market securitization, its infrastructures.

The decision of the named problems will lead to that operations on securitization both mortgage loans, and other actives become enough widespread operation, will expand the credit policy of banks, will allow to change the fundamental nature of bank operations, in a special way providing liquidity at active increase in a credit portfolio of bank [3-6]. All it will serve as a motive power for expansion of scales securitization as new phenomenon in bank activity. At the same time expansion of volumes of consumer crediting, leasing transactions at already formed secondary market, legislative base, an infrastructure, system of guarantors and state support will allow to provide a basis for development securitization and these kinds of actives [7].

Results in any sphere of business depend on presence and efficiency of use of financial resources which provide organization ability to live. And the care of the finance is the starting moment of activity of any subject of managing, and in the conditions of market economy these questions have paramount value.

As the basic sources of the information for the analysis of formation and placing of financial resources of the organization accounting balance sheets, reports on profits and losses, on capital change, on movement of funds, on target use of the received means, the appendix to balance and other forms of the reporting, the data of primary and analytical accounting which decipher serve and detail separate articles of balance.

The source of means (source of financing) is a conditional name of any article in the passive side of the balance sheet treated as set of the capital of proprietors and obligations, i.e. debts, the enterprises before the third parties and each article of a passive means, as a matter of fact, the contribution of the corresponding person (proprietors, creditors, state structures, banks, etc.) in financing of actives of the given organization [8].

At the normal functioning those organizations who has financed its activity, can receive the means enclosed by them in the volume marked in balance or even exceeding it. Isolation of sources of means in balance is predetermined by an essence and the nature of double record.

Sources of means appear as result of purposeful actions, for example, reception of the bank credit means inflow of money resources on the settlement account and simultaneously occurrence in a passive of balance of a source of these means in the form of debts against bank.
At the same time sources can arise in a sense spontaneously as result of financial and economic activity, for example, revealing of financial result for the accounting period is accompanied by necessity of charge and profit tax payment that the debts under taxes and tax collections are expressed in isolation in a passive of balance of article as a part of sources there is a new source.

Quite often this or that source is formed for the purpose of identification of the plan of use of means of firm. It is necessary to underline especially that the source of means should be distinguished from actually means. The source is the artificial design caused by application of double record in the account.

The estimation of structure of sources is spent both internal, and external users of the accounting information. According to it approaches to the analysis so, external users (banks, suppliers are various, etc.) estimate change of a share of own means of the organization in sheathe to the sum of sources of means from the point of view of financial risk at the conclusion of transactions [9].

The risk accrues with reduction of a share of own sources of means. The internal analysis of structure of sources of property is connected with an estimation of alternative variants of financing of activity of the organization. The basic criteria of a choice are risk degree, the price of a source of financing, a condition of its use, term of payment of a debt, etc. the alternative sources of financing accessible to the organization, assume various degree of vulnerability from risk, up to possibility of loss of control over the organization $[10,11]$.

It is thus important to estimate, where own and extra means, in fixed capital and in other non-current assets or in mobile circulating assets are put. Though from the financial point of view increase of a share of circulating assets in property and is favorable for the organization, it does not mean that all sources should go only on growth of circulating assets. The analysis of structure and structure of financial sources begins with an estimation of their dynamics and internal structure. Thus special attention given to the analysis of movement of sources of extra means, considering such passives, as long-term both short-term credits and loans, accounts payable, including the advance payments received from buyers and customers, calculations under dividends, other short-term passives.

The tendency of change of volume and share of credits of banks (and loans), which have been not extinguished in time [12-16]

Thus comes to light. The increase in their absolute sum and a share testifies to presence at the organization of serious financial difficulties. Then comparison of vectors of structural dynamics of an active and a passive of balance and an estimation of the factors influencing a parity of own and extra 


\begin{tabular}{|c|c|c|c|c|c|c|}
\hline \multirow{4}{*}{ Impact Factor: } & ISRA (India) & $=3.117$ & SIS (USA) & $=0.912$ & ICV (Poland) & $=6.630$ \\
\hline & ISI (Dubai, UAE & $=0.829$ & РИНЦ (Russia & $=\mathbf{0 . 1 5 6}$ & PIF (India) & $=1.940$ \\
\hline & GIF (Australia) & $=0.564$ & ESJI (KZ) & $=8.716$ & IBI (India) & $=4.260$ \\
\hline & JIF & $=1.500$ & SJIF (Morocco & $=5.667$ & OAJI (USA) & $=0.350$ \\
\hline
\end{tabular}

sources, and, hence, and on financial stability of the organization are spent.

To number of the major factors caused by internal and external working conditions of the organization, as a rule, carry:

- Distinctions of sizes of interest rates for the credit and rates of dividends. If interest rates for the credit below rates of dividends it is necessary to raise a share of extra means. The share of own means is expedient for increasing when the rate of the dividend below the interest rate for the credit;

- Reduction or expansion of activity of the organization in this connection the requirement for attraction of extra means for formation of necessary commodity-material stocks is reduced or increases;

- Accumulation of excessive or poorly used stocks of the out-of-date equipment, materials, finished goods, the goods for sale, derivation of means in formation of a doubtful debt receivable that also leads to attraction of additional extra means;
- Use factoring operations (sale of debts of debtors to bank).

Result of perfect calculations is comparison of attraction of additional sources of financial resources and their use.

Comparison of indicators of articles of a passive of balance allows estimating the sums of the means involved in addition from external sources. The analysis of distribution of profit together with data on the added amortization for the accounting period allows estimating the means involved in a turn of the organization at the expense of internal sources.

The analysis final stage is check of correctness of placing of property of the organization.

Thus, at the present stage essentially increases of priority researches of the mechanism of formation, placing and use of sources of financing. For maintenance of financial stability and financial safety of any organization studying of classification of sources of financing is important.

\section{References:}

1. Kudina, M. (2012). Financial management. (p.256). Moscow: ID FORUM: INFRA TH.

2. Leontev, V. E., Bocharov, V. V., \& Radkovsky, N. P. (2010). Investment. (p.416). Moscow: INFRA TH.

3. Lukasevich, I. J. (2013). Investment. (p.413). Moscow: INFRA TH.

4. Nikolaev, M. A. (2010). Investment activity. (p.336). Moscow: INFRA TH.

5. Proskurin, V. K. (2012). The analysis and financing of innovative projects. (p.112). Moscow: INFRA TH.

6. Shevchyuk, V. I., \& Bevzeluk A. A. (2010). Organization and financing of investments. (p.196). Mn.: BGEU.

7. Vakulenko/Zima/, J. S., \& Peshkov, E. P. (1999). Feature of development of investment process in the Russian economy//The collection of work «Market economy and financially-credit relations». Rostov on Don, РГЭА.

8. Vakulenko/Zima/, J. S. (1999). The regional investment policy in a transition period: problems and sources of their financing. Collection of work of 58th scient. conf. (p.234). Rostov on Don: Rostov on Don Pedag. Univ.

9. Uljanitskaja, N. M., \& Winter J. U. (2002) S. problem of an estimation of degree of usefulness of an investment climate in region (on an example of the Rostov region)// Collection of work «Multifactorial development of transitive economy» / (pp.14-19). Rostov on Don Pedag. Univ.

10. Sechko, N. N. (2014). Innovative strategy of the small and average enterprises of Belarus: the comparative analysis [Text]. the Bulletin of the Mogilyov State University after A. A. Kuleshov, № 1, 43-52.

11. Sorokin, A. P. (2006). Innovative activity of the organizations as the factor of their effective development [Text]. Labor safety and social protection, № 1, 61-64.

12. Bocharov, V. V., \& Leontev, B. E. (2004). Corporate finance. (p.236). Moscow: Peter.

13. Blank, I. A. (2004). Financial management. (p.388). K: Nika-centre.

14. Braily, P., \& Myers, C. (1997). Principles of corporate finance. (p.431). Moscow: Olympusbusiness.

15. Gleams, I. (2005). Financial management. Problems. (p.142). Moscow: PDL.

16. Kovalev, V. V. (2000). Financial management. (p.165). Moscow: Finance and statistics.

17. Pavlova, L. N. (1998). Finance of the enterprises. (p.165). Moscow: the Finance UNITI. 